\title{
ANALISIS HUBUNGAN DINAS PUBLIK ANTARA PEGAWAI PEMERINTAH DENGAN PERJANJIAN KERJA DAN PEMERINTAH
}

\section{Nurmalita Ayuningtyas Harahap}

Fakultas Hukum, Universitas Islam Indonesia

In Article 1 point 4 of Law no. 5 of 2014 states that, "Government Employees with Work Agreements, hereinafter abbreviated as PPPK, are Indonesian citizens who meet certain requirements, who are appointed based on work agreements for a certain period of time in order to carry out government duties." One of the characteristics of civil servants who work in government agencies is to have a relationship between civil servants and the government. This relationship is known as opebare dienstbetrekking or Public Service Relations. A voluntary agreement or a special contract due to the appointment that gives rise to the HDP is a one-sided legal act (aanstelling) from the Government. This one-sided government action was marked by the issuance of a Decree of appointment given to Civil Servants. Meanwhile, PPPK is appointed based on a work agreement. Appointments with this work agreement will be understood by their appointments based on ordinary contracts or two-sided government actions. The purpose of this study is to find out the appointment of PPPK is normatively reviewed and analyzes related to PPPK which can be classified or not as Civil Servants who have the characteristics of Public Service Relations with the Government due to the appointment of PPPK based on a work agreement. This type of research is a normative juridical research based on primary and secondary legal materials. The study was carried out using a conceptual approach and a statutory approach. This research is a library research.
\end{abstract}

ARTICLE INFO

\section{Keywords:}

Public Service Relations; PPPK; Government

\section{Cite this paper:}

Harahap, N. A. (2021). Analisis Hubungan Dinas Publik Antara Pegawai Pemerintah Dengan Perjanjian Kerja Dan Pemerintah. Widya Yuridika: Jurnal Hukum, $4(2)$.

\section{Scope Article}

Civil Law

\section{PENDAHULUAN}

Pegawai Negeri atau yang disebut juga dengan Aparatur Negara merupakan sarana yang sangat penting dalam mencapai tujuan negara, sebagaimana yang tercantum dalam dalam Pembukaan UUD 1945 (Alinea ke-IV). Tujuan tersebut antara lain adalah melindungi segenap bangsa dan seluruh tumpah darah Indonesia. Tujuan pembangunan nasional adalah untuk membentuk satu masyarakat adil dan makmur, seimbang materiil dan spiritualnya berdasarkan Pancasila dalam wilayah NegaraKesatuan Republik Indonesia. Kelancaran pelaksanaan pemerintah danpembangunan nasional, terutama sekali tergantung pada pesempurnaan Aparatur Negara. ${ }^{1}$ Aparatur Negara atau yang merupakan sarana

\footnotetext{
${ }^{1}$ M Nata Saputra. 1988 .Hukum Administrasi Negara. Jakarta: Rajawali Press. hlm. 98.
} 
kepegawaian ini memiliki kedudukan dan peranan yang sangat penting dalam penyelenggaraan fungsi pemerintahan. ${ }^{2}$ Fungsi pemerintahan yang dimaksud dirumuskan sebagai kegiatan negatif sebagai segala macam kegiatan penguasa yang tidak dapat disebutkan suatu kegiatan perundang-undangan atau peradilan. ${ }^{3}$ Antara lain kegiatan pemerintahan yang melingkupi menjalankan undang-undang dan pelayanan publik. Pada hakikatnya setiap manusia membutuhkan pelayanan tersebut, karena pelayanan tidak dapat dipisahkan dengan kehidupan manusia. Dalam hubungan masyarakat dengan pemerintah, masyarakat setiap waktu akan menuntut pelayanan publik yang berkualitas dari aparat pemerintah (birokrat), atau dalam hal ini pegawai negeri. ${ }^{4}$

Terkait dengan sarana kepegawaian yang sangat penting dalam menjalankan fungsi pemerintahan, yang salah satunya adalah pelayanan publik bagi masyarakat, maka perkembangan konsep tentang sarana kepegawaianpun telah membawa pula kepada tentang kepegawaian. Dalam Undang-Undang No. 5 Tahun 2014 tentang Aparatur pergeseran secara normatif, yaitu dalam peraturan perundang-undangan yang mengatur Sipil Negara, menyebut istilah Pegawai Negeri yang dikenal dalam Undang-Undang No. 43 Tahun 1999 yang menggantikan Undang-Undang No. 8 tahun 1974 yang kini sudah dicabut atau tidak berlaku lagi dengan istilah Aparatur Sipil Negara. Semangat dikeluarkannya UU ASN adalah untuk meweujudkan sistem pemerintahan yang demokratis, bersih, dan berwibawa yang merupakan prioritas utama bagi rakyat dan pemerintahan di Indonesia.Sejalan dengan pemerintah untuk menata sistem pemerintahan yang baik. Sejalan dengan perkembangan ilmu pengetahuan dan tekhnologi, di bidang pemerintahan telah menjadi perubahan yang mendasar. Salah satu perubahan itu adalah perwujudan tata pemerintah yang demokratis dan baik. Salah satu unsut penyelenggara pemerintahan yang perlu memperoleh perhatian dalam upaya reformasi itu adalah penataan Aparatur Sipil Negara..$^{5}$ Dalam menjalankan perannya sebagai pelayan publik yang diberikan pemerintah kepada masyarakat, ASN sering dijadikan indikator keberhasilan suatu sistem penyelenggaraan pemerintahan. ${ }^{6}$

Dalam Pasal 1 angka 1 UU ASN dinyatakan bahwa, "Aparatur Sipil Negara yang selanjutnya disingkat ASN adalah profesi bagi pegawai negeri sipil dan pegawai pemerintah dengan perjanjian kerja yang bekerja pada instansi pemerintah." Kemudian, di dalam Pasal 1 angka 4 UU ASN menyebutkan bahwa, "Pegawai Pemerintah dengan Perjanjian Kerja yang selanjutnya disingkat PPPK adalah warga negara Indonesia yang memenuhi syarat tertentu, yang diangkat berdasarkan perjanjian kerja untuk jangka waktu tertentu dalam rangka melaksanakan tugas pemerintahan."

Salah satu ciri dari Pegawai Negeri yang bekerja pada instansi pemerintah tersebut adalah memiliki hubungan antara Pegawai Negeri dengan Pemerintah. Hubungan ini disebut sebagai opebare dienstbetrekking atau Hubungan Dinas Publik (HDP). Inti dari HDP ini adalah kewajiban bagi pegawai negeri untuk tunduk pada pengangkatan dalam beberapa macam jabatan tertentu yang berakibat bahwa pegawai yang bersangkutan tidak menolak (menerima tanpa syarat) pengangkatannya dalam satu jabatan yang telah ditentukan oleh pemerintah. ${ }^{7}$ Maka dapat dikatakan bahwa, segi hukum pengangkatan yang menimbulkan HDP tersebut merupakan perjanjian yang bersifat "perjanjian sukarela" antara pemerintah

\footnotetext{
2 W. Riawan Tjandra. 2014 . Hukum Sarana Pemerintahan. Yogyakarta: Cahaya Atma Pustaka. hlm. 173.

3 Philipus M. Hadjon. 2008. Pengantar Hukum Administrasi Indonesia. Yogyakarta: Gadjah Mada Press. hlm.6.

${ }^{4}$ Muh. Jufri Dewa. 2011. Hukum Administrasi Negara dalam Prespektif Pelayanan Publik. Kendari: Unhalu Press. hlm.97.

5 Sri Hartini dan Tedi Sudrajat. 2017. Hukum Kepegawaian di Indonesia (Edisi Kedua). Ctk Pertama. Jakarta: Sinar Grafika. hlm,4.

${ }^{6}$ Elim Riedel Christmas Pio, 2018.Tanggung Jawab Administrasi Aparatur Sipil Negara terhadap Perbuatan Melawan Hukum dalam Menjalankan Kewenangannya, Juranl Lex Administratum. 6 (4), 2018. hlm.112.
}

${ }^{7}$ S.F.Marbun. 2012. Hukum Administrasi Negara I. Yogyakarta: FH UII Press. hlm 259. 
kepada pegawai negeri, atau disebut pula adanya suatu kontrak istimewa, ${ }^{8}$ sehingga terjadi kewajiban bagi pegawai negeri untuk tunduk pada pengangkatan dan tidak boleh menolak yang kemudian lahir HDP tersebut. Perjanjian yang bersifat sukarela atau adanya kontrak istimewa dikarenakan pengangkatan yang menimbulkan HDP tersebut merupakan perbuatan hukum bersegi satu (aanstelling) dari Pemerintah. ${ }^{9}$ Tindakan pemerintahan bersegi satu tersebut ditandai dengan keluarnya Surat Keputusan (SK) pengangkatan yang diberikan untuk Pegawai Negeri.

Seperti yang telah dijelaskan sebelumnya, bahwa secara normatif kini Pegawai Negeri dikenal dengan sebutan ASN, yang mana ASN dibagi menjadi pegawai negeri sipil (PNS) dan pegawai pemerintah dengan perjanjian kerja (PPPK). Jika, merujuk pada pernyataan di Pasal 1 angka 4 UU ASN yang telah dibahas pula sebelumnya, bahwa PPPK diangkat berdasarkan perjanjian kerja. Pengangkatan dengan perjanjian kerja ini akan dipahami dengan pengangkatanya didasarkan pada kontrak atau tindakan pemerintahan bersegi dua, dengan dikeluarkannya surat perjanjian kerja yang diterima oleh PPPK. Dalam hal yang demikian, maka akan timbul permasalahan mengenai apakah PPPK dapat digolongkan sebagai Pegawai Negeri yang memiliki ciri khas Hubungan Dinas Publik (HDP) dengan Pemerintah? Sebab adanya HDP dimulai dengan dikeluarkannya SK Pengangkatan, yang merupakan tindakan pemerintahan bersegi satu. Berangkat dari permasalahan tersebut, maka terdapat dua rumusan masalah, pertama, bagaimana pengangkatan PPPK ditinjau secara normatif? kedua, apakah PPPK dapat digolongkan sebagai Pegawai Negeri yang memiliki ciri khas Hubungan Dinas Publik (HDP) dengan Pemerintah dikarenakan pengangkatan PPPK yang didasarkan pada perjanjian kerja? Tujuan dalam penelitian ini adalah ingin mengetahui pengangkatan PPPK ditinjau secara normative dan menganalisis terkait PPPK yang dapat digolongkan atau tidak sebagai Pegawai Negeri yang memiliki ciri khas Hubungan Dinas Publik (HDP) dengan Pemerintah dikarenakan pengangkatan PPPK yang didasarkan pada perjanjian kerja.

\section{METODE}

Jenis penelitian ini adalah penelitian yuridis normatif ini didasarkan kepada bahan hukum primer dan sekunder, yaitu penelitian yang mengacu kepada norma-norma yang terdapat dalam peraturan perundang-undangan. ${ }^{10}$ Penelaahan dilakukan dengan pendekatan konseptual (conceptual approach) dan pendekatan perundang-undangan (statute approach), merupakan pendekatan yang beranjak dari pandangan-pandangan dan doktrin-doktrin yang berkembang di dalam ilmu hukum, guna menemukan ide-ide yang. melahirkan pengertian, konsep, dan asas hukum yang relevan, sebagai sandaran dalam membangun suatu argumentasi hukum dalam memecahkan isu hukum yang dihadapi. ${ }^{11}$ Penelitian ini merupakan penelitian kepustakaan (Library Research), yakni suatu kajian yang menggunakaan literatur kepustakaan dengan cara mempelajari buku-buku, kitab-kitab maupun infomasi lainnya yang ada relevansinya dengan ruang lingkup pembahasan. ${ }^{12}$

\section{HASIL DAN PEMBAHASAN}

\section{A. APARATUR SIPIL NEGARA}

Aparatur Sipil Negara merupakan istilah secara normatif yang dikenal dalam UndangUndang No. 5 Tahun 2014 tentang Aparatur Sipil Negara, sedangkan secara teoritik dikenal

\footnotetext{
${ }^{8}$ Moh. Mahfud.1988.Hukum Kepegawaian. Yogyakarta: FH UII Press. hlm, 4.

${ }^{9} \mathrm{Ibid}, \mathrm{hlm} .5$.

${ }^{10}$ Soeryono Soekanto.1984.Pengantar Penelitian Hukum. Jakarta: UI Press. hlm.20.

${ }^{11}$ Peter Mahmud Marzuki. 2013. Penelitian Hukum. Jakarta: Kencana Prenada Media Group. hlm.135-136.

${ }^{12}$ Bambang Sungono. 2009. Metodologi Penelitian Hukum. Jakarta: PT. Raja Grafindo Persada. hlm. 189
} 
sebagai Pegawai Negeri. Oleh karena itu sebelum dilakukan pembahasan secara normatif, dalam bagian ini akan dibahas secara teoritik terlebih dahulu. Menurut Kamus Umum Bahasa Indonesia W.J.S. Poerwadinata, kata pegawai berarti: "orang yang berkerja pada Pemerintah (Perusahaan dan sebagainya)." Sedangkan "negeri" berarti: "negara" atau "pemerintah." Jadi pegawai negeri adalah orang yang bekerja pada Pemerintah atau negara. ${ }^{13}$ Hoge Raad (HR) pada keputusannya tanggal 30 Januari 1911, merumuskan pengertian Pegawai Negeri sebagai berikut: “ Pegawai Negeri adalah seorang yang diangkat oleh penguasa dalam suatu jabatan umum, yang melaksanakan sebagian dari tugas-tugas Negara atau alat-alat perlengkapan. Berdasarkan pendapat Hoge Raad tadi, Mr. J.E. Jonhkers lebih lanjut menjelaskan, yang kemudian dikutip oleh Victor M. Situmorang, sebagai berikut ${ }^{14}$ : Maka untuk dapat dianggap sebagai pegawai negeri harus memenuhi unsurunsur.

1. Pengangkatan oleh penguasa umum;

2. Dalam suatu jabatan umum, dan;

3. Melakukan sebagaian dari tugas-tugas atau alat-alat perlengkapannya

Kranenburg memberikan pengertian dari Pegawai Negeri, yaitu pejabat yang ditunjuk, jadi pengertian tersebut tidak termasuk terhadap mereka yang memangku jabatan mewakili seperti anggota parlemen, presiden dan sebagainya. Sedangkan Logemann dengan menggunakan kriteria yang bersifat materiil mencermati hubungan antara negara dengan Pegawai Negeri dengan memberikan pengertian Pegawai. ${ }^{15}$ Pegawai Negeri sebagai unsur Aparatur Negara, Abdi Negara dan Abdi Masyarakat yang bertugas menyelenggarakan pemerintahan dan pembangunan. Dalam hal ini kedudukan Pegawai Negeri menjadi sangat penting sebab lancar dan tidak lancarnya pemerintahan dan pembangunan negara tidak terlepas dari peranan dan keikutsertaan Pegawai Negeri. ${ }^{16}$

Berbicara tentang Pegawai Negeri tidak akan terlepas pula dari peraturan perundang-undangan yang mengatur tentang Pegawai Negeri tersebut. Dalam hal undangundang, perihal pegawai negeri ini diatur dalam Undang-Undang No. 5 Tahun 2014 tentang Aparatur Sipil Negara, dimana Undang-Undang No. 5 Tahun 2014 telah diberlakukan dan menggantikan Undang-Undang No. 8 Tahun 1974 yang telah digantikan dengan UndangUndang No. 43 Tahun 1999. Dalam Undang-Undang No.5 Tahun 2014 tersebut peristilahan Pegawai Negeri dikenal dengan Aparatur Sipil Negara. Disebutkan dalam Pasal 1 angka 1 bahwa Aparatur Sipil Negara yang selanjutnya disingkat ASN adalah profesi bagi pegawai negeri sipil dan pegawai pemerintah dengan perjanjian kerja yang bekerja pada instansi pemerintah. Kemudian Pasal 1 angka 2 menyebutkan bahwa Pegawai Aparatur Sipil Negara yang selanjutnya disebut Pegawai ASN adalah pegawai negeri sipil dan pegawai pemerintah dengan perjanjian kerja yang diangkat oleh pejabat pembina kepegawaian dan diserahi tugas dalam suatu jabatan pemerintahan atau diserahi tugas negara lainnya dan digaji berdasarkan peraturan perundang-undangan. Pasal 1 angka 3 menyebutkan Pegawai Negeri Sipil yang selanjutnya disingkat PNS adalah warga negara Indonesia yang memenuhi syarat tertentu, diangkat sebagai Pegawai ASN secara tetap oleh pejabat pembina kepegawaianuntuk menduduki jabatan pemerintahan. Kemudian Pasal 1 angka 4 disebutkan bahwa Pegawai Pemerintah dengan Perjanjian Kerja yang selanjutnya disingkat PPPK adalah warga negara Indonesiayang memenuhi syarat tertentu, yang diangkat

\footnotetext{
13 Rozali Abdullah. 1986. Hukum Kepegawaian. Ctk: pertama, Jakarta: Rajawali Pres. hlm.13.

14 Ahmad Ghufron dan Sudarsono. 1991. Hukum Kepegawaian di Indonesia. Ctk Ke-1, Jakarta: Rineka Cipta, hlm. 12.

15 Sri Hartini, et.al. 2014. Hukum Kepegawaian di Indonesia, Ctk ketiga, Jakarta: Sinar Grafika, hlm.31-32.

${ }^{16}$ Ibid,hlm. 4.
} 
berdasarkan perjanjian kerja untuk jangka waktu tertentu dalam rangka melaksanakan tugas pemerintahan.

\section{B. HUBUNGAN DINAS PUBLIK}

Dalam kajian teori, disebutkan bahwa terdapat hubungan antara Pegawai Negeri dengan Negara yang disebut openbare dienstbetrekking (hubungan dinas publik). Adapun openbare dienstbetrekking yang melekat pada hubungan-hubungan hukum kepegawaian ini lebih merupakan hubungan subordinatie antara atasan dengan bawahan. ${ }^{17}$ Lebih lanjut, ada beberapa pendapat tentang hubungan dinas publik, antara lain ${ }^{18}$ :

a. Menurut Logemann hubungan dinas publik adalah bilamana seseorang mengikat dirinya untuk tunduk pada perintah dari pemerintah untuk melakukan sesuatu atau beberapa macam jabatan yang dalam melakukan suatu atau beberapa jabatan dihargai dengan pemberian gaji dan beberapa keuntungan lain. Hal ini berarti inti dari hubungan dinas publik adalah kewajiban bagi pegawai yang bersangkutan untuk tunduk pada pengangakatan dalam beberapa macam jabatan tertentu yang berakibat bahwa pegawai yang besangkutan tidak menolak (menerima tanpa syarat) pengangkatannya dalam satu jabatan yang telah ditentukan oleh pemerintah di mana sebaliknya pemerintah berhak mengangkat seseorang pegawai dalam jabatan tertentu tanpa harus adanya penyesuaian kehendak dari yang bersangkutan (bersegi satu).

b. Kajian hubungan dinas publik ini berkaitan dengan segi pengangkatan Pegawai Negeri. Hubungan antarpegawai negeri dengan negara dari segi pengangkatan ini dkenal dengan teori Contrac Suigeneris. Teori ini dikemukakan oleh Buys sebagai berikut: Dalam Contrac Suigeneris disyaratkan pegawai negeri harus setia dan taat selama menjadi Pegawai Negeri, meskipun dia setiap saat mengundurkan diri. Dari pendapat Buys ini dapat disimpulkan bahwa selama menjadi Pegawai Negeri Sipil, mereka tidak dapat melaksanakan bahwa selama menjadi Pegawai Negeri Sipil mereka tidak dapat melaksanakan hak-hak asasinya secara penuh. Oleh karena itu, apabila PNS akan melaksnaakan hak-hak asasinya secara penuh, pemerintah dapat menyatakan yang bersangkutan bukanlah orang yang diperlukan bantuannya oleh pemerintah. Pendapat Buys ditentang oleh Y. Helskreek dengan mengemukakan pendapatnya sebagai berikut. Jika hak asasi pegawai negeri itu dibatasi berarti pemerintah melakukan perbuatan inskonstitusional atau melanggar UUD. Dari dua pendapat tersebut, hukum kepegawaian di Indoensia lebih cenderung menganut ke Buys.

c. Menurut Philipus M. Hadjon, kajian Hukum Administrasi lebih memandang hubungan Hukum kepegawaian dimaksud sebagai hubungan openbare dienstbetrekking (hubungan dinas publik) terhadap negara (pemerintah), Openbare dienstbetrekking yang melekat pada hubungan kepegawaian itu lebih merupakan hubungan subordinatie antara bawahan dan atasan.

Jadi inti dari hubungan dinas publik atau yang disingkat sebagai HDP itu adalah adanya kewajiban bagi pegawai yang bersangkutan untuk tunduk pada pengangkatan dalam beberapa macam jabatan tertentu yang berakibat bahwa pegawai yang bersangkutan tidak menolak (menerima tanpa syarat) pengangkatannya dalam satu jabatan yang telah ditentukan oleh pemerintah. Sebaliknya pemerintah berhak mengangkat seseorang pegawai dalam jabatan tertentu tanpa harus adanya persesuaian kehendak dari yang bersangkutan. ${ }^{19}$ Logemann, Kranenburg-Vegtig, Van Praag, Krabbe, Prins menyatakan bahwa hubungan dinas publik itu timbul karena suatu persesuaian kehendak antara pegawai dengan

17 Sri Hartini, et.al.. op.cit. hlm. 15.

18 Ibid.. hlm. 15-16.

${ }^{19}$ Moh. Mahfud MD. op.cit.hlm. 2-3. 
pemerintah. Pendapat ini didasari oleh suatu pemikiran bahwa pengangkatan pegawai adalah suatu hasil titik temu antara kehendak Pemerintah dalam membutuhkan pegawai dan kehendak pegawai untuk bekerja pada pemerintah. Sedangkan menyatakan bahwa hubungan dinas publik adalah akibat yang muncul dari suatu perbuatan hukum yang bersegi satu yang dilakukan oleh Pemerintah yakni penunjukkan (aanstelling) orang yang bersangkutan dalam jabatannya Selanjutnya, Muchsan dalam Riawan Tjandra menyimpulkan bahwa hubungan dinas publik tetap merupakan suatu akibat dari perbuatan hukum yang bersegi satu (sefihak=unilateral). ${ }^{20}$

\section{TINDAKAN HUKUM PEMERINTAHAN}

Tindakan pemerintahan (bestuurhandeling) adalah tindakan atau perbuatan yang dilakukan oleh administrasi negara dalam melaksanakan tugas pemerintahan. ${ }^{21}$ Beberapa bentuk tindakan yang berbeda dapat dilakukan oleh badan atau pejabat pemerintahan dapat melakukan tindakan menurut hukum publik maupun hukum privat. Tindakan hukum publik berupa konsensual dalam bentuk kontrak pemerintahan (administrative contract) atau tindakan sepihak (unilateral) yang menawarkan beberapa instrumen yang dapat dipilih oleh badan atau pejabat pemerintahan. Selanjutnya, badan atau pejabat pemerintahan dapat memutuskan untuk melakukan nyata/ faktual (real act) atau tindakan menerbitkan keputusan yang bersifat mengatur. Tindakan pengatur dapat berupa pengaturam yang melahirkan akibat hukum ke luar (eksternal) bagi individua tau badan hukum di luar pemerintahan, atau berakibat ke dalam (internal) bagi badan atau pejabat pemerintahan sendiri seperti peraturan kebiajakan atau pedoman-pedoman. ${ }^{22}$ Instrumen yang mengikat iternal hanya mengikat untuk badan atau pejabat pemerintahan sendiri dan hanya tertuju bagi badan atau pejabat pemerintahan. Namun demikian, instrumen tersebut dpat secara tidak langsung menimbulkan akibat terhadap hak publik. Instrumen tindakan sepihak yang memiliki akibat ke luar, misalnya adalah keputusan tata usaha negara (admistrative act). Badan atau pejabat pemerintahan bebas untuk memilih berbagai macam tindakan yang tersedia sepanjang itu tidak dilarang oleh undang-undang. ${ }^{23}$

Tindakan hukum (legal act) adalah tindakan yang dimaksudkan untuk menimbulkan akibat hukum yang berarti tindakan tersebut harus dimaksudkan memiliki akibat hukum yang terkait hubungan antara badan atau pejabat pemerintahan dengan satu atau lebih orang atau badan hukum. Istilah akibat hukum pada umumnya berarti menciptakan, mengubah, atau mengakhiri suatu hubungan hukum. Sementara itu, yang dimaksud hubungan hukum dapat berupa hak, kewajiban, kewenangan, atau kedudukan hukum (legal status). ${ }^{24}$

Di Kalangan para sarjana terjadi perbedaan pendapat mengenai sifat tindakan hukum pemerintahan. Sebagian menyatakan bahwa perbuatan hukum yang terjadi alam lingkup hukum publik bersifat sepihak atau hubungan hukum bersegi satu (enzijdige). Bagi mereka tidak ada perbuatan hukum publik yang bersegi dua, tidak ada perjanjian yang diatur oleh hukum publik. ${ }^{25}$ Bilamana antara pemerintah dengan seorang partikelir diadakan suatu perjanjian, maka hukum yang mengatur perjanjian itu senantiasa hukum privat. Perjanjian itu suatu perbuatan hukum yang bersegi dua karena diadakan oleh dua kehendak (yang ditentukan secara sukarela), yakni suatu persesuaian kehendak (wilsovereenstemming) antara dua pihak. ${ }^{26}$ Sementara sebagaian yang lain menyatakan, ada perbuatan hukum pemerintahan bersegi dua (tweezijdige). Mereka mengakui adanya perjanjian yang diatur

\footnotetext{
${ }^{20}$ Riawan Tjandra, op.cit.hlm.151.

${ }^{21}$ A'an Efendi dan Freddy Poernomo. 2017. Hukum Administrasi, Jakarta: Sinar Grafika. hlm. 178.

22 Ibid. hlm.184.

${ }^{23}$ Ibid.

24 Ibid. hlm.186.

${ }^{25}$ Ridwan HR. 2016. Hukum Administrasi Negara, Jakarta: Rajawali Pres. hlm. 117-118.

26 Ibid.
} 
oleh hukum publik seperti kortverband contract atau perjanjian kerja yang berlaku selama jangka pendek. Meskipun dikenal adanya tindakan pemerintah bersegi dua, namun argumentasi masing-masing penulis tampak bahwa pada prinsipnya semua tindakan pemerintah dalam menyelenggarakan tugas-tugas publik lebih merupakan tindakan sepihak atau bersegi satu. Indroharto bahkan menyebutkan bahwa tindakan hukum tata usaha negara itu selalu bersifat sepihak, karena tindakan hukum tersebut pada akhirnya tergantung kehendak sepihak dari badan atau jabatan tata usaha yang memiliki wewenang pemerintahan untuk berbuat demikian. Pada perjanjian jangka pendek (kortverband contract), yang dijadikan contoh hubungan hukum dua pihak dalam hukum publik, harus dianggap sebagai cara pelaksanaan tindakan pemerintahan bukan esensi dari tindakan hukum pemerintahan itu sendiri. ${ }^{27}$

Dengan kata lain, sebagaimana disebutkan W.F.Prins, yang lebih lazim terjadi ialah pernyataan kehendak pemerintah dijadikan tiik berat dalam pelaksanaannya, sedangkan kehiatan pihak yang bersangkutan, yang melahirkan awal usahanya, menjadi tergeser ke belakang, sekalipun kemudian ditentukan bahwa pihak yang bersangkutan harus menyetujui penawaran yang diberikan oleh pemerintah kepadanya. ${ }^{28}$

Terkait dengan tindakan hukum pemerintah, maka akan terkait dengan instrumen hukum pemerintahan. Sebab instrumen hukum tersebut akan tercipta dari adanya suatu tindakan hukum pemerintah. Instrumen hukum pemerintahan ini antara lain adalah Keputusan Tata Usaha Negara dan Instrumen Hukum Keperdataan. ${ }^{29}$ Surat Keputusan berkaitan dengan tindakan hukum pemerintah di bidang publik. Dari berbagai definisi tersebut dapat ditarik kesimpulan bahwa beschikking (keputusan), ialah suatu perbuatan hukum publik yang bersegi satuu, yang dilakukan oleh alat pemerintah (dalam arti sempit) berdasarkan kekuasaan atau kewenangan istimewa dengan maksud terjadi perubahan hubungan hukum. Keputusan Tata Usaha Negara merupakan suatu penetapan tertulis yang dikeluarkan oleh badan atau pejabat Tata Usaha Negara yang berisi tindakan hukum Tata Usaha Negara yang berdasarkan peraturan perundang-undangan yang berlaku, bersifat konkret, individual dan final, yang menimbulkan akibat hukum bagi seseorang atau badan hukum perdata (Pasal 1 angka 3 UU No.5 Tahun 1986).

Dalam pergaulan keperdataan, sebagaimana yang telah diterjemahkan dalam Ridwan, Pemerintah sebagaimana manusia dan hukum privat dapat terlibat dalam pergaulan hukum privat. Pemerintah melakukan jual beli, sewa-menyewa, membuat perjanjian dan mempunyai hak miliki. Pemerintah juga bertanggungjawab ketika terjadi perbuatan melawan hukum yang dilakukan pemerintah. Perlu diketahui bahwa, sebagaimana yang telah diterjemahkan oleh Ridwan, tindakan hukum keperdataan dari pemerintah itu tidak dijalankan oleh organ pemerintahan, tetapi oleh badan hukumnya, yang dilakukan oleh wakilnya, yaitu pemerintah. ${ }^{30}$ Adapun dalam hal ini dapat terjadi instrumen hukum berupa kontrak pemerintah. Menurut Meinhard Scroder, kontrak pemerintah adalah kesepakatan berdasarkan hukum publik yang mencerminkan gagasan koordinasi dan kedudukan yang sama antara negara dan warga negara. Dalam kontrak pemerintah, kewajiban kedua pihak adalah hasil dari negosiasi dan ditetapkan dalam bentuk kesepakatan formal. Dalam beberapa bidang, kontrak pemerintah menggantikan keputusan pemerintah (keputusan tata usaha negara) atau persiapan untuk keputusan pemerintah yang kemudian. Kontrak pemerintah dapat berdasarkan ketentuan yang tegas dalam undang-undang atau diskresi pejabat yang berwenang untuk memilih instrumen tindakan pemerintah. ${ }^{31}$

\footnotetext{
27 Ibid. hlm.118-119.

28 Ibid.

${ }^{29}$ A'an Efendi dan Freddy Poernomo. op,cit. hlm.186.

30 Ibid. hlm.214.

31 Ibid. hlm. 193.
} 
Kontrak pemerintah terikat oleh prinsip legalitas dan kedudukan yang sama bagi para pihak dalam kontrak yang berbeda dengan kontrak privat. Asas kebebasan berkontrak tidak dapat dikaitkan dengan dengan kontrak pemerintah. Kontrak pemerintah menjadi berlaku sah melalui pernyataan kehendak para pihak untuk melahirkan hasil tertentu dalam kontrak yang telah disepakati. Di Indonesia dalam Rantjangan Undang-Undang peradilan Tata Usaha Negara yang disusun Lembaga Pembinaan Hukum Nasional pada tahun 1967, kontrak pemerintah (disebut perikatan) menjadi kompetensi Peradilan Tata Usaha Negara. Pasal 1 ayat (1) menetapkan sebagai berikut ${ }^{32}$ :

"Peradilan Tata Usaha Negara memutus sengketa Tata Usaha Negara dalam bidangbidang:

a. Padjak;

b. Bea-tjukai;

c. Perumahan;

d. Kepegawaian;

e. Ganti Kerugian;

f. Perikatan."

Pada penjelasan umum diberikan penjelasan aoa yang dimaksud perikatan sebagai berikut: " Jang dimaksud dengan perikatan ialah, seseorang membuat perikatan dengan instansi pemerintah dan kemudian instansi itu melakukan tindakan jang merugikan orang itu, maka orang tersebut dapat menggugat instansi itu di muka peradilan Tata Usaha Negara."

\section{HUBUNGAN HUKUM}

Hubungan hukum (rechtsbetrekkingen) diartikan sebagai hubungan antara dua atau lebih subyek hukum, hubungan mana terdiri atas ikatan antara individu dengan individu, antara individu dengan masyarakat atau antara masyarakat yang satu dengan masyarakat yang lain. Dalam hubungan hukum ini hak dan kewajiban pihak yang satu berhadapan dengan hak dan kewajiban pihak yang lain. ${ }^{33}$ Hubungan hukum tercermin pada hak dan kewajiban yang diberikan dan dijamin oleh hukum. Hak dan kewajiban timbul karena adanya peristiwa hukum, menurut Van Apeldorn "peristiwa hukum adalah peristiwa yang berdasarkan hukum menimbulkan atau menghapuskan hak." 34 Berdasarkan peristiwa hukum maka hubungan hukum dibagi menjadi 3 (tiga) jenis yaitu35:

1. Hubungan hukum yang bersegi satu (eenzijdige rechtsbetrekkingen), dimana hanya terdapat satu pihak yang berwenang memberikan sesuatu, berbuat sesuatu atau tidak berbuat sesuatu (Pasal 1234 KUHPerdata) sedangkan pihak yang lain hanya memiliki kewajiban.

2. Hubungan hukum bersegi dua (tweezijdige rechtsbetrekkingen), yaitu hubungan hukum dua pihak yang disertai adanya hak dan kewajiban pada masing-masing pihak, kedua belah pihak masing-masing berwenang/berhak untuk meminta sesuatu dari pihak lain, sebaliknya masing-masing pihak juga berkewajiban memberi sesuatu kepada pihak lainnya, misalnya hubungan kerja antara pengusaha dengan pekerja/buruh.

3. Hubungan antara satu subyek hukum dengan semua subyek hukum lainnya, hubungan ini terdapat dalam hal hak milik (eigendomrecht).

\footnotetext{
32 Ibid. hlm.196.

33 Soeroso. 2006. Pengantar Ilmu Hukum. Ctk Kedelapan.Jakarta: Sinar Grafika. hlm. 269.

34 Ibid.hlm.271-272.

35 Ibid.
} 
Dalam Hukum Administrasi Negara, hubungan hukum (rechtsbetrekking) antara pemerintah, dalam kapasitasnya sebagai wakil dari jabatan pemerintah bukan dalam kapasitasnya. Selaku wakil dari badan pemerintahan, dengan seseorang atau badan hukum perdata tidak berada dalam kedudukan yang sejajar. Pemerintah memiliki kedudukan khusus (de overheid als bijzonder person), sebagai satu-satunya pihak yang diserahi kewajiban untuk mengatur dan menyelenggarakan kepentingan umum di mana dalam rangka melaksanakan kewajiban ini kepada pemerintah diberikan wewenang membuat peraturan perundang-undangan, menggunakan paksaan pemerintahan, atau menerapkan sanksi-sanksi hukum. Kedudukan pemerintah yang tidak memiliki oleh seseorang atau badan hukum perdata ini menyebabkan hubungan hukum antara pemerintah dengan seseorang dan badan hukum perdata bersifat ordinatif. Berbeda halnya dengan hubungan hukum perdata bersifat sejajar. Pemerintah, dalam kapasitasnya sebagai wakil dari badan hukum pemerintahan, bukan sebagai wakil dari jabatan pemerintahan, dapat mengadakan hubungan hukum berdasarkan hukum perdata dengan kedudukan yang sejajar atau tidak berbeda dengan seseorang atau badan hukum perdata. Meskipun hubungan hukumnya bersifat ordinatif, pemerintah tidak dapat melakukan tindakan hukum secara bebas dan semena-mena terhadap warga negara. ${ }^{36}$

Sebagaimana telah disebutkan, tindakan hukum pemerintah tetap terikat pada asas yang mendasari tindakan tersebut yaitu asas legalitas. Kalaupun kemudian dikenal adanya tindakan hukum dua pihak atau lebih, maka ini hanya menyangkut mengenai cara-cara merealisasikan tindakan hukum tersebut. Di atas disebutkan bahwa tindakan hukum dua pihak diatur dengan peraturan bersama. Kemunculan peraturan bersama pada hakikatnya hanyalah menyangkut cara untuk melaksanakan tugas dan urusan pemerintahan, yaitu ketika tugas dan urusan pemerintahan tertentu kebetulan ada kesamaan dengan organ pemerintahan lainnya atau karena pada tujuan agar pelaksanaan tugas dan urusan tersebut dapat terselenggara secara efketif dan efisien dengan cara dilaksanakan bersama-sama. ${ }^{37}$

Pada kenyataannya, tidak semua urusan pemerintahan dapat diselenggarakan sendiri oleh organ pemerintah yang diberi kewenangan untuk menjalankan tugas dan urusan tersebut, serta tidak semua tugas dan urusan pemerintahan dapat dijalankan secara bersama-sama dengan organ pemerintahan lainnya Hal ini karena ruang lingkup urusan pemerintahan itu demikian luas dan kompleks, sehingga untuk efektivitas dan efisiensi diperlukan pula keterlibatan pihak swasta, yang diwujudkan dengan cara kerja sama atau perjanjian. Tindakan hukum pemerintahan yang dilakukan dengan melibatkan pihak swasta ini disebut sebagai tindakan hukum campuran (de gemengd rechtshandeling). ${ }^{38}$ Di dalam praktik, urusan pemerintahan itu tidak selalu dijadikan sendiri oleh pemerintah seperti Presiden sebagai kepala pemerintahan beserta perangakatnya atau Kepala Daerah beserta perangkatnya, namun dijalankan pula oleh pihak-pihak lain bahkan pihak swasta yang diberi wewenang untuk menjalankan urusan pemerintah. E.Utrecht menyebutkan beberapa cara pelaksanaan urusan p.emerintahan,yaitu ${ }^{39}$ :

1. Yang bertindak ialah administrasi negara sendiri;

2. Yang bertindak ialah subjek hukum (=badan hukum) lain yang tidak termasuk administrasi negara dan mempunyai hubungan istimewa atau hubungan biasa dengan pemerintah;

3. Yang bertindak ialah subjek hukum lain yang tidak termasuk administrasi negara dan menjalankan pekerjaannya berdasarkan suatukonsesi atau berdasarkan izin (vergunning) yang diberikan oleh pemerintah.

\footnotetext{
36 Ridwan HR. op.cit. hlm..119-120.

37 Ibid. hlm.120-121.

38 Ibid.hlm.121

39 Ibid.hlm.121-122.
} 
4. Yang bertindak ialah subjek hukum lain yang tidak termasuk administrasi negara dan diberi subsidi pemerintah.

5. Yang bertindak ialah pemerintah bersama-sama dengan subjek hukum lain yang bukan administrasi negara dan kedua belah pihak itu tergabung dalam bentuk kerja sama (vorm van samenwerking) yang diatur oleh hukum privat.

6. Yang bertindak ialah Yayasan yang didirikan oleh pemerintah atau diawasi pemerintah.

7. Yang bertinda ialah subjek hukum lain yang bukan administrasi negara, tetapi diberi suatu kekuasaan memerintah (delegasi peraturan perundang-undangan).

Sepanjang prinsip negara hukum, yaitu asas wetamtigheid van bestuur masih dijadikan sendi utama penyelenggaraan pemerintahan, maka tetaplah bahwa prinsip tindakan hukum pemerintahan yang bersifat sepihak tersebut tidak dapat dikesampingkan, meskipun tugas-tugas dan pekerjaan pemerintahan dapat dijalankan dengan cara kerja sama (samenwerking), perjanjian (overeenkomst), perizinan (vergunning), konsesi (consessie), dan sebagainya. Di samping dikenal karakteristik tidak hukum pemerintahan bersifat sepihak, dikenal pula karakteristik tindakan hukum pemerintahan yang bersifat terikat, fakultatif, dan bebas. Karakteristik tindakan hukum demikian ini berkenaan dengan dasar bertindak yang dimiliki oleh organ pemerintahan, yaitu kewenangan. Sebagaimana telah dijelaskan bahwa kewenangan ini ada yang bersifat terikat, fakultatif, dan bebas. ${ }^{40}$

\section{ANALISIS HUBUNGAN DINAS PUBLIK ANTARA PPPK DAN PEMERINTAH}

Peristilahan Pegawai Negeri secara normatif seperti yang telah disebutkan pada sub bab sebelumnya terdapat dalam peraturan perundang-undangan tentang kepegawaian yang berlaku saat ini, yaitu Undang-Undang No. 5 Tahun 2014 tentang Aparatur Sipil Negara. Dalam undang-undang istilah pegawai negeri disebut dengan Aparatur Sipil Negara atau disingkat dengan ASN. Dalam UU ASN, menurut Pasal 1 angka 2 dinyatakan bahwa, Pegawai Aparatur Sipil Negara yang selanjutnya disebut Pegawai ASN adalah pegawai negeri sipil dan pegawai pemerintah dengan perjanjian kerja yang diangkat oleh pejabat pembina kepegawaian dan diserahi tugas dalam suatu jabatan pemerintahan atau diserahi tugas negara lainnya dan digaji berdasarkan peraturan perundang-undangan. Kemudian yang disebut Pegawai Pemerintah dengan Perjanjian Kerja atau yang disingkat dengan PPPK menurut Pasal 1 angka 4, adalah warga negara Indonesia yang memenuhi syarat tertentu, yang diangkat berdasarkan perjanjian kerja untuk jangka waktu tertentu dalam rangka melaksanakan tugas pemerintahan. Jika merujuk kepada UU ASN tersebut, maka PPPK bagian dari ASN, sedangkan secara teoritik ASN sendiri merupakan Pegawai Negeri.

Secara normatif, terkait dengan pengangkatan dengan perjanjian kerja bagi PPPK ini ada di beberapa ketentuan peraturan perundang-undangan Kepegawaian, Pasal 98 ayat (1) Undang-Undang No. 5 Tahun 2014 tentang Aparatur Sipil Negara menyatakan bahwa, pengangkatan calon PPPK ditetapkan dengan keputusan Pejabat Pembina Kepegawaian. Kemudian di dalam ayat (2) dinyatakan, masa perjanjian kerja paling singkat 1 (satu) tahun dan dapat diperpanjang sesuai kebutuhan dan berdasarkan penilaian kinerja. Disini terlihat bahwa terdapat pengangkatan melalui perjanjian kerja. Disamping itu pada Pasal 105 dalam Undang-Undang No. 5 Tahun 2014 terdapat pemutusan hubungan perjanjian kerja bagi PPPK, antara lain dalam Pasal 105 ayat (1) disebutkan bahwa, pemutusan hubungan perjanjian kerja PPPK dilakukan dengan hormat karena jangka waktu perjanjian kerja berakhir; meninggal dunia; atas permintaan sendiri; perampingan organisasi atau kebijakan pemerintah yang mengakibatkan pengurangan PPPK; atau tidak cakap jasmani dan/atau rohani sehingga tidak dapat menjalankan tugas dan kewajiban sesuai perjanjian kerja yang disepakati. Di dalam ketentuan tersebut terlihat pula pemutusan hubungan perjanjian kerja bagi PPPK salah satunya dilakukan jika jangka waktu perjanjian kerja 
berakhir. Maka jelas bahwa PPPK mempunyai hubungan perjanjian kerja bagi pemerintah sebagai dasar pengangkatan PPPK menurut UU ASN.

Kemudian, peraturan lebih teknis, yaitu terdapat dalam Peraturan Pemerintah No. 49 Tahun 2018 tentang Manajemen Pegawai Pemerintah dengan Perjanjian Kerja juga mengatur mengenai perjanjian kerja PPPK. Pada Pasal 29 ayat (3) dinyatakan bahwa, Pengangkatan calon PPPK sebagaimana diimaksud pada ayat (1) ditetapkan dengan keputusan PPK. Kemudian pada Pasal 31 ayat (1), disebutkan bahwa PPPK yang telah mendapatkan nomor induk sebagaimana dimaksud dalam Pasal 29 ayat (4) melaksanakan tugas jabatan berdasarkan penetapan pengangkatan oleh PPK. Penetapan dalam hal ini ditandai dengan dikeluarkannya surat keputusan (SK) oleh PPK. Selanjutnya pada Pasal 31 ayat (3) disebutkan, keputusan pengangkatan sebagaimana dimaksud pada ayat (1) ditetapkan setelah penandatanganan perjanjian kerja oleh Calon PPPK. Pasal 31 ayat (4) menyatakan pula, keputusan pengangkatan sebagaimana dimaksud pada ayat (1) dijadikan sebagai dasar dimulainya hubungan perjanjian kerja PPPK dengan Instansi pemerintah. Dapat dilihat bahwa penetapan keputusan yang dikeluarkan oleh PPK akan dikeluarkan setelah adanya perjanjian kerja. Maka, dapat dikatakan bahwa tindakan hukum awal yang dilakukan pemerintah adalah mengeluarkan perjanjian kerja dan setelah penandatanganan perjanjian kerja oleh Calon PPPK. Namun, menurut Pasal 31 ayat (4) SK tetap dijadikan sebagai dasar dimulainya hubungan kerja. Adapun ketentuan perjanjian kerja terdapat dalam Pasal 33, yaitu memuat tentang tugas, target kinerja, masa perjanjian kerja, hak dan kewajiban, larangan, dan sanksi. Oleh karena itu, pengangkatan PPPK diawali dengan perjanjian kerja dan diikuti dengan adanya Surat Keputusan pengangkatan oleh Pejabat Pembina Kepeagawaian selaku pejabat yang memiliki kewenangan untuk mengangkat PPPK tersebut.

Setelah dibahas mengenai pengangakatan PPPK secara normatif, maka selanjutnya akan dibahas apakah PPPK dapat digolongkan sebagai Pegawai Negeri yang memiliki ciri khas Hubungan Dinas Publik (HDP) dengan Pemerintah dikarenakan pengangkatan PPPK yang didasarkan pada perjanjian kerja? Seperti yang telah dikemukakan di sub bab sebelumnya, bahwa suatu tindakan hukum pemerintah akan melahirkan hubungan hukum tertentu. Terdapat beberapa bentuk tindakan yang dapat dilakukan, yaitu pemerintah dapat melakukan tindakan publik maupun privat, yang mana hal ini akan berpengaruh kepada hubungan hukumnya. Sebab jika diketahui maka hubungan hukumpun memiliki bentuk yang berbeda sesuai dengan tindakan yang dilakukan pemerintah. Ada hubungan hukum yang bersegi satu (eenzijdige rechtsbetrekkingen), dimana hanya terdapat satu pihak yang berwenang memberikan sesuatu, berbuat sesuatu atau tidak berbuat sesuatu (Pasal 1234 KUHPerdata) sedangkan pihak yang lain hanya memiliki kewajiban dan ada pula yang memiliki hubungan hukum bersegi dua (tweezijdige rechtsbetrekkingen), yaitu hubungan hukum dua pihak yang disertai adanya hak dan kewajiban pada masing-masing pihak, kedua belah pihak masing-masing berwenang/berhak untuk meminta sesuatu dari pihak lain, sebaliknya masing-masing pihak juga berkewajiban memberi sesuatu kepada pihak lainnya, misalnya hubungan kerja antara pengusaha dengan pekerja/buruh. ${ }^{41}$ Dalam hal ini, seringkali hubungan hukum bersegi satu identik dengan tindakan publik pemerintah. Contohnya adalah dikeluarkannya instrumen hukum berupa Surat Keputusan (SK). Dalam pembentukan dan pengesahan hanya datang dari satu pihak, SK tersebut hanya terdapat satu pihak yang berwenang memberikan sesuatu, berbuat sesuatu atau tidak berbuat sesuatu. Artinya pula yang menentukan ketentuan didalam instrumen hukum SK tersebut adalah pemerintah. Hal ini berarti, terdapat hubungan yang bersifat sepihak dalam pengangatan yang ada di ketentuan Pasal 31 di PP No. 49 Tahun 2018 tentang Manajemen Pegawai Pemerintah dengan Perjanjian Kerja, sebab terdapat SK dari Pejabat Pembina Kepegawaian. Sedangkan bila pemerintah terlibat dalam tindakan hukum privat maka

${ }^{41}$ Soeroso. loc.cit. 
hubngannya lebih kepada hubungan bersegi dua. Dalam hal ini seperti dinyatakakan sebelumnya, hubungan bersegi dua ditandai dengan hak dan kewajiban pada masingmasing pihak dan kedua belah pihak memiliki kewenangan atau hak untuk meminta dari sesuatu dari pihak lain dan sebaliknya. Hal ini contohnya adalah dikeluarkannya perjanjian. Contoh dalam pengangkatan PPPK terdapat pula dalam Pasal 31 di PP No. 49 Tahun 2018 tentang Manajemen Pegawai Pemerintah terdapat pula perjanjian.

Terkait dengan perjanjian kerja tersebut, pada dasarnya menurut hubungan keperdataan, hubungan kerja berdasarkan perjanjian kerja secara umum berasaskan kebebasan berkontrak (pacta sunt servanda), artinya bahwa perjanjian tersebut mengikat para pihak sebagaimana undang-undang. Konsekuensi dari perjanjian adalah para pihak wajib mematuhi isi perjanjian, apabila tidak mematuhi isi perjanjian maka pihak tersebut telah melakukan wanprestasi. Namun perjanjian kerja sedikit berbeda dengan perjanjian pada umumnya, yaitu perjanjian kerja biasanya telah dibuat oleh pemberi kerja dalam bentuk kontrak baku. ${ }^{42}$ Kontrak baku dalam perjanjian kerja ini pada dasarnya para pihak tidak mempunyai peluang untuk merundingkan atau meminta perubahan. Klausula yang belum dibakukan hanyalah beberapa hal, misalnya yang menyangkut jenis, harga, jumlah warna, tempat, waktu, dan beberapa hal lainnya yang spesifik dari objek yang diperjanjikan. Dengan kata lain, yang dibakukan bukan formulir perjanjian tersebut tetapi klausulklausulnya. Oleh karena itu, dapat dikatakan perjanjian kerja bagi PPPK termasuk pada kontrak atau perjanjian yang bersifat baku, datangnya sepihak dari pemerintah. Apa yang ditentukan secara baku adalah klausul tentang tugas, target kinerja, masa kerja, hak, kewajiban, larangan, dan sanksi dari pemerintah. Dalam hal klausul yang bersifat baku dari perjanjian PPPK tersebut,

Beralih dari perjanjian sebagai instrumen dalam pengangkatan PPPK, kini akan dibahas mengenai Hubungan Dinas Publik (HDP). Dalam teori hukum kepegawaian, untuk menentukan status seseorang sebagai Pegawai Negeri dipergunakan 2 (dua) macam kriteria, yaitu pertama, Berdasarkan adanya hubungan dinas publik, yaitu manakala seseorang mengingatkan diri untuk tunduk pada pemerintah dan melakukan jabatan atau tugas tertentu, kedua, berdasarkan pengangkatan (aanstelling), yaitu diangkat melalui suatu surat keputusan (beschikking) guna ditetapkan secara sah sebagai Pegawai Negeri. ${ }^{43}$ Dalam hal ini yang akan dibahas adalah PPPK dipandang dalam statusnya sebagai Pegawai Negeri berdasarkan kriteria adanya suatu hubungan dinas publik atau yang disingkat dengan HDP. Sedangkan telah disinggung di sub bab sebelumnya terkait dengan pengertian HDP dalah adanya kewajiban bagi pegawai yang bersangkutan untuk tunduk pada pengangkatan dalam beberapa macam jabatan tertentu yang berakibat bahwa pegawai yang bersangkutan tidak menolak (menerima tanpa syarat) pengangkatannya dalam satu jabatan yang telah ditentukan oleh pemerintah. Sebaliknya pemerintah berhak mengangkat seseorang pegawai dalam jabatan tertentu tanpa harus adanya persesuaian kehendak dari yang bersangkutan. ${ }^{44}$ Adapun openbare dienstbetrekking yang melekat pada hubungan hukum kepegawaian itu lebih cenderung pada hubungan sub-ordinatie antara atasan dengan bawahan. ${ }^{45}$ Maka terjalin hubungan sub-ordinate antara pemerintah dengan Pegawai Negeri sebagai atasan dan bawahan. Adanya suatu hubungan HDP ini adalah ditandai dengan dikeluarkannya Keputusan Tata Usaha Negara oleh Pemerintah atau

\footnotetext{
42 Dwi Aryanti Ramadhani dan Iwan Erar Joesoef. 2020. Perlindungan Hukum Pegawai Pemerintah Dengan Perjanjian Kerja (PPPK) dalam Konsep Perjanjian Kerja Waktu Tertentu di Institusi Perguruan Tinggi, Jurnal Yuridis 7 (1), hlm.17.

43 W. Riawan Tjandra. op.cit. hlm.151.

44 Moh. Mahfud MD. op.cit.,hlm. 2-3.

45 Edwyn Hari Prasetia. 2019. Kompetensi Aparatur Sipil Negara dalam Peningkatan Mutu Pelayanan Publik. Jurnal Jurist-Diction. 2 (6),hlm.2080.
} 
Pejabat yang mengangkat Pegawai Negeri tersebut melalui tindakan hukum bersegi satu (enzijdige).

Maka, kedudukan seseorang sebagai Pegawai Negeri secara yuridis formal harus ditetapkan melalui SK pengangkatan sebagai Pegawai Negeri. Sedangkan, substansi dari SK pengangakatan tersebut adalah penetapan berlakunya hubungan dinas publik antara seorang pegawai negeri dengan negara. Berkaitan dengan prespektif hukum dari hubungan dinas publik, Muchsan dalam Riawan Tjandra mengemukakan permasalahan apakah hubungan dinas publik tersebut merupakan suatu akibat hukum dari perbuatan hukum dari yang bersegi satu (sepihak=unilateral) ataukah akibat hukum dari perbuatan hukum yang bersegi dua (bilateral). ${ }^{46}$ Kemudian, yang perlu diketahui adalah meskipun demikian timbul dan berakhirnya lembaga dinas publik itu tidak tergantung pada pengangkatan dalam atau pemberhentian dari satu jabatan. Sebab ada pegawai negeri yang tidak punya jabatan (seperti non aktif) namun masih mempunyai hubungan dinas publik, sebaliknya ada orang yang mempunyai jabatan (pejabat) tetapi tidak mempunyai hubungan dinas publik ( seperti orang yang menjadi pejabat berdasarkan perjanjian kerja). Jadi yang terpenting dari hubungan dinas publik adalah kewajiban pegawai yang bersangkutan untuk tunduk pada pengangkatan oleh pemerintah dalam satu atau beberapa macam jabatan tertentu. ${ }^{47}$

Jika kita melihat pengangkatan Pegawai Pemerintah dengan Perjanjian Kerja (PPPK), maka PPPK pengangkatannya disertai dengan perjanjian kerja namun disamping itu pula disertai dengan SK. Dalam Pasal 29 ayat (3), sebagaimana yang telah dibahas sebelumnya disebutkan bahwa pengangkatan calon PPPK ditetapkan dengan keputusan PPK. Keputusan yang dimaksud ini adalah Surat Keputusan atau SK. Sedangkan dalam Pasal 31 ayat (3) disebutkan, keputusan pengangkatan sebagaimana dimaksud pada ayat (1) ditetapkan setelah penandatanganan perjanjian kerja oleh Calon PPPK. Namun, walaupun telah terjadi tindakan hukum keperdataan, menurut penulis perjanjian kerja tersebut hanya memuat terkait dengan ketentuan-ketentuan yang disepakati oleh seseorang jika ia telah menjadi Calon PPPK atau yang nantinya menjadi PPPK, bukan sebagai landasan suatu hubungan hukum yang lahir dan memberikan kedudukannya sebagai seorang pegawai negeri. Karena jika melihat pada Pasal 33 di PP No. 48 Tahun 2019, perjanjian yang ditentukan secara baku tersebut memuat tentang tugas, target kinerja, masa perjanjian kerja, hak dan kewajiban, larangan, dan sanksi. Sedangkan Surat Keputusan (SK) pengangkatan PPPK yang dikeluarkan oleh PPK itulah yang menjadi dasar dari hibungan dinas publik atau lahirnya kedudukan PPPK sebagai seorang pegawai negeri. Terlebih hubungan hukum yang terjadi antara PPPK dengan pemerintah tersebut sebenarnya merupakan hubungan hukum yang lahir dalam lingkup hukum publik. Sebab terdapat keberadaan pemerintah didalamnya. Selain itu tindakan hukum dengan kontrak yang bersifat baku, yang dapat dikatakan datangnya sepihak dari pemerintah. Dalam hal ini pula terdapat kesesuaian dengan setelah dikeluarkannya perjanjian kerja yang bersifat sepihak (dalam mengatur klasulanya) kemudian keluarlah SK yang sifatnya sepihak.

Jika melihat pada tindakan hukum terlebih dilihat dari lingkup dan sifat tindakannya, terdapat pandangan dari kalangan para sarjana terjadi perbedaan pendapat mengenai sifat tindakan hukum pemerintahan. Telah dibahas pada sub bab sebelumnya, bahwa terdapat sebagian menyatakan bahwa perbuatan hukum yang terjadi alam lingkup hukum publik bersifat sepihak atau hubungan hukum bersegi satu (enzijdige). Bagi mereka tidak ada perbuatan hukum publik yang bersegi dua, tidak ada perjanjian yang diatur oleh hukum publik. ${ }^{48}$ Bilamana antara pemerintah dengan seorang partikelir diadakan suatu perjanjian, maka hukum yang mengatur perjanjian itu senantiasa hukum privat. Perjanjian itu suatu perbuatan hukum yang bersegi dua karena diadakan oleh dua kehendak (yang ditentukan

\footnotetext{
${ }^{46}$ Riawan TJandra.loc.cit.

47 Ibid.

48 Ridwan HR. . loc,cit.
} 
secara sukarela), yakni suatu persesuaian kehendak (wilsovereenstemming) antara dua pihak. ${ }^{49}$

Sementara sebagaian yang lain menyatakan, ada perbuatan hukum pemerintahan bersegi dua (tweezijdige). Mereka mengakui adanya perjanjian yang diatur oleh hukum publik seperti kortverband contract atau perjanjian kerja yang berlaku selama jangka pendek. Meskipun dikenal adanya tindakan pemerintah bersegi dua, namun argumentasi masing-masing penulis tampak bahwa pada prinsipnya semua tindakan pemerintah dalam menyelenggarakan tugas-tugas publik lebih merupakan tindakan sepihak atau bersegi satu. Indroharto bahkan menyebutkan bahwa tindakan hukum tata usaha negara itu selalu bersifat sepihak, karena tindakan hukum tersebut pada akhirnya tergantung kehendak sepihak dari badan atau jabatan tata usaha yang memiliki wewenang pemerintahan untuk berbuat demikian. Pada perjanjian jangka pendek (kortverband contract), yang dijadikan contoh hubungan hukum dua pihak dalam hukum publik, harus dianggap sebagai cara pelaksanaan tindakan pemerintahan bukan esensi dari tindakan hukum pemerintahan itu sendiri. ${ }^{50}$ Contoh dari perjanjian jangka pendek (kortverband contract), inilah yang kemudian kurang lebih sama jika dibandingan dengan perjanjian yang dimiliki oleh PPPK. Semua tindakan pemerintah dalam tugas publik termasuk pengangkatan PPPK merupakan tindakan sepihak, meskipun terdapat didalamnya tindakan pemerintah bersegi dua yang melahirkan hubungan bersegi dua antara seseorang dengan pemerintah. Oleh karena itu, yang menjadi penanda lahirnya hubungan dinas publik adalah SK yang diterbitkan oleh PPK untuk seseorang yang diangkat menjadi PPPK dan pada SK itulah terjadi hubungan bersegi satu antara pemerintah dengan PPPK, SK tersebut menjadi dasar PPPK dapat digolongkan sebagai pegawai negeri. sedangkan perjanjian tersebut yang memuat tentang tugas, target kinerja, masa perjanjian kerja, hak dan kewajiban, larangan, dan sanksi, lebih mengarah pada cara pelaksanaan tindakan pemerintah, yaitu terkait dengan pengangkatan PPPK secara sepihak.

\section{PENUTUP}

Secara normatif, terkait dengan pengangkatan dengan perjanjian kerja bagi PPPK ini ada di beberapa ketentuan peraturan perundang-undangan Kepegawaian. Antara lain dalam Pasal 98 ayat (1) dan Pasal 105 Undang-Undang No. 5 Tahun 2014 tentang Aparatur Sipil Negara. Dalam peraturan tersebut terdapat ketentuan bahwa PPPK diangkat dengan perjanjian kerja. Selain itu secara tehknis terdapat dalam Peraturan Pemerintah No. 49 Tahun 2018 tentang Manajemen Pegawai Pemerintah dengan Perjanjian Kerja juga mengatur mengenai perjanjian kerja PPPK. Pada Pasal 29 ayat (3) dinyatakan bahwa, Pengangkatan calon PPPK sebagaimana diimaksud pada ayat (1) ditetapkan dengan keputusan PPK. Selanjutnya pada Pasal 31 ayat (3) disebutkan, keputusan pengangkatan sebagaimana dimaksud pada ayat (1) ditetapkan setelah penandatanganan perjanjian kerja oleh Calon PPPK. Adapun ketentuan perjanjian kerja terdapat dalam Pasal 33, yaitu memuat tentang tugas, target kinerja, masa perjanjian kerja, hak dan kewajiban, larangan, dan sanksi. Oleh karena itu, pengangkatan PPPK diawali dengan perjanjian kerja dan diikuti dengan adanya Surat Keputusan pengangkatan oleh Pejabat Pembina Kepeagawaian selaku pejabat yang memiliki kewenangan untuk mengangkat PPPK tersebut. Merujuk pada berbagai ketentuan tersebut, pengangkatan PPPK diawali dengan pendatanganan surat perjanjian kerja dan Surat Keputusan (SK) yang dikeluarkan oleh PPK.

PPPK dapat dikategorikan sebagai pegawai negeri, hal ini dikarenakan terdapat SK, dan yang menjadi penanda lahirnya hubungan dinas publik adalah SK yang diterbitkan oleh PPK tersebut untuk seseorang yang diangkat menjadi PPPK dan pada SK itulah terjadi hubungan bersegi satu antara pemerintah dengan PPPK, SK tersebut menjadi dasar PPPK dapat

49 Ibid.

50 Ibid, hlm.118-119. 
digolongkan sebagai pegawai negeri. sedangkan perjanjian tersebut yang memuat tentang tugas, target kinerja, masa perjanjian kerja, hak dan kewajiban, larangan, dan sanksi, lebih mengarah pada cara pelaksanaan tindakan pemerintah, yaitu terkait dengan pengangkatan PPPK secara sepihak.

\section{DAFTAR PUSTAKA}

\section{Buku}

Abdullah. Rozali . (1986). Hukum Kepegawaian. Ctk: pertama. Jakarta: Rajawali Press.

Bambang. Sungono. (2009). Metodologi Penelitian Hukum. Jakarta: PT. Raja Grafindo Persada.

Dewa. Muh. Jufri. (2011). Hukum Administrasi Negara dalam Prespektif Pelayanan Publik. Kendari: Unhalu Press.

Efendi. A'an dan Freddy Poernomo. (2017). Hukum Administrasi. Jakarta: Sinar Grafika.

Ghufron. Ahmad dan Sudarsono. (1991). Hukum Kepegawaian di Indonesia. Ctk Ke-1, Jakarta: Rineka Cipta.

Hadjon. Philipus M. (2008). Pengantar Hukum Administrasi Indonesia. Yogyakarta: Gadjah Mada Press.

Hartini, Sri. et.al.. (2014). Hukum Kepegawaian di Indonesia, Ctk ketiga. Jakarta: $\quad$ Sinar Grafika.

. dan Tedi Sudrajat. (2017). Hukum Kepegawaian di Indonesia (Edisi Kedua). Ctk Pertama. Jakarta: Sinar Grafika.

Mahfud. Moh. (1988). Hukum Kepegawaian. Yogyakarta: FH UII Press.

Marbun. S.F.. (2012). Hukum Administrasi Negara I. Yogyakarta: FH UII Press.

Marzuki. Mahmud Peter. (2013). Penelitian Hukum. Jakarta: Kencana Prenada Media Group.

Ridwan HR. (2016). Hukum Administrasi Negara, Jakarta: Rajawali Pres.

Saputra. M Nata .1988. Hukum Administrasi Negara. Jakarta: Rajawali Press.

Soekanto. Soeryono. (1984). Pengantar Penelitian Hukum. Jakarta: UI Press.

Soeroso. (2006). Pengantar Ilmu Hukum. Ctk Kedelapan.Jakarta: Sinar Grafika.

Tjandra. W. Riawan. (2014). Hukum Sarana Pemerintahan. Yogyakarta: Cahaya Atma Pustaka.

\section{Peraturan Perundang-Undangan}

Undang-Undang No. 5 Tahun 2014 tentang Aparatur Sipil Negara.

Peraturan Pemerintah No. 48 Tahun 2019 tentang Manajemen Pegawai Pemerintah dengan Perjanjian Kerja. 


\section{Jurnal}

Elim Riedel Christmas Pio. 2018. Tanggung Jawab Administrasi Aparatur Sipil

Negara terhadap Perbuatan Melawan Hukum dalam Menjalankan Kewenangannya, Juranl Lex Administratum. 6 (4), 2018, 112.

Dwi Aryanti Ramadhani dan Iwan Erar Joesoef. 2020. Perlindungan Hukum

Pegawai Pemerintah Dengan Perjanjian Kerja (PPPK) dalam Konsep Perjanjian Kerja Waktu Tertentu di Institusi Perguruan Tinggi, Jurnal Yuridis 7 (1), 17.

Edwyn Hari Prasetia. 2019. Kompetensi Aparatur Sipil Negara dalam Peningkatan

Mutu Pelayanan Publik. Jurnal Jurist-Diction. 2 (6), 2080. 